\title{
Concentrations of Large and Giant Hygroscopic Particles in the Atmosphere
}

\author{
By T. Okita \\ Department of Industrial Health and Hygiene, Institute of Public Health \\ (Manuscript received 9 February 1962)
}

\begin{abstract}
The mass spectra of large and giant hygroscopic particles in the air are measured by means of a hand-operated impactor and a microscope. Our results are in good agreement with the spectra obtained by several investigators at different places of the world. The concentrations of the giant particles are largest on the sea or on the coast and decrease to one tenth at distances of about $100 \mathrm{~km}$ from the coast. Further decrease of the concentration is observed at cloud base. These observations suggest that the main source of the giant hygroscopic particles is the ocean.

It is further found that there are enough giant hygroscopic nuclei for the production of drizzle at the stratus cloud base.
\end{abstract}

\section{Introduction}

Woodcook (1952) measured the concentration of sea-salt nuclei in marine air and proposed the importance of the giant salt nuclei as the triggering of warm rain formation. Ludlam (1951) and Ogiwara and Kobayashi (1954) theoretically pointed out that the giant salt nuclei with mass above $100 \mu \mu \mathrm{g}$ can act as the nuclei of large cloud droplets of radii above 20 microns, which will become raindrops by the accretion with smaller droplets. The growth of salt droplets by condensation was also measured by Keith and Arons (1954) and by Isono and others (1956). They confirmed the validity of the theory of Ogiwara and Kobayashi.

Therefore the measurements of geographical and seasonal variation of the giant hygroscopic nuclei concentration is one of the important problems in cloud physics. Nevertheless only a few data of the concentration have been obtained especially at inland area.

\section{Method of measurements}

We made the samplings of the hygroscopic particles by means of the impactor shown in Fig. 1. The hole diameter of the impactor is $1 \mathrm{~mm}$ and under the hole a square glass plate with the length of one side $2 \mathrm{~cm}$ which

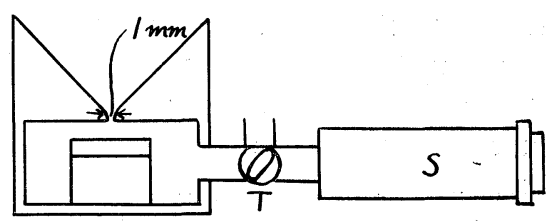

Fig. 1. Impactor.

S: Syringe

T: Three-way cock

is coated with silicon resin is placed. About three liters of air is drawn by means of a hand-operated $100-\mathrm{ml}$ injection syringe. Between the impactor and syringe a three-way cock is inserted and when the syringe is pushed back to its original position the cock is so turned that the air in the syringe is ejected without passing the impactor. The size measurement and counting of hygroscopic particles collected on the glass plate are made by means of a small glass chamber and an optical microscope of magnification 200. At the bottom of the chamber two sheets of ringshaped blotting papers soaked with aqueous solution of sodium chloride are placed surrounding the glass plate. The humidity in the chamber is varied with the concentration of the sodium chloride solution. The humidity is controlled to be 95 per cent. At the humidity 95 per cent hygroscopic particles on the hydrophobic slide absorb water vapor 
to form hemispherical droplets. We have an empirical formula $r_{95 \%}=0.36 D_{95 \%}$ for sodium chloride droplets, where $r_{95} \%$ is the radius of the spherical droplets in the air and $D_{95 \%}$ is the diameter of the droplets on the slide.

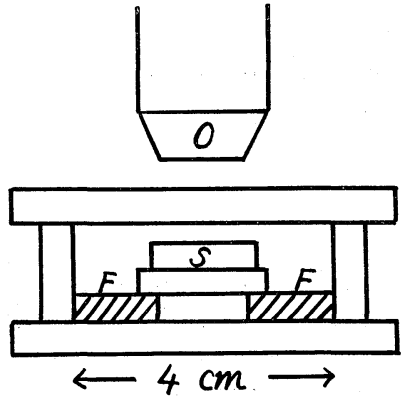

Fig. 2. Chamber with controlled humidity.

$\mathrm{O}$ : Objective of microscope

S : Glass slide

F : Filter. paper

Although the chamber shown in Fig. 2 is very simple, it is found that the error of the measurement of $D_{95 \%}$ due to the fluctuation of room air temperature is within 10 per cent.

Although it is expected that there are various kinds of hygroscopic particles in the air, we assume that all the particles consist of sodium chloride. Then the mass of the salt particles can be determined using the relationship between relative humidity and the concentration of aqueous solution of the salt

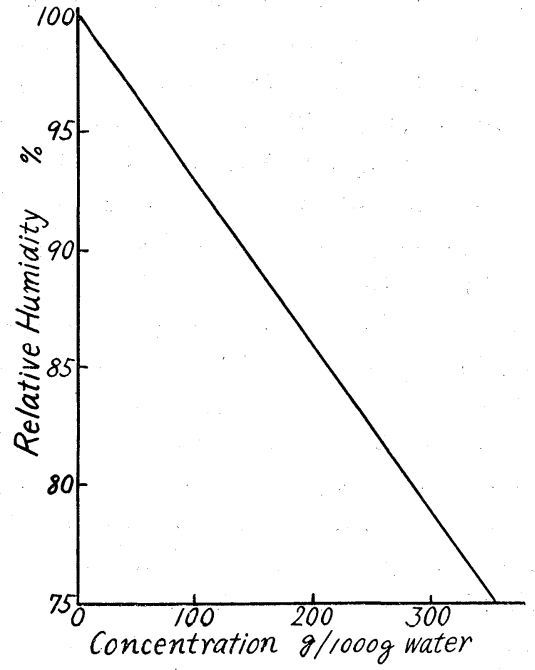

Fig. 3. Relation between concentration of aqueous solution of $\mathrm{NaCl}$ and equilibrium relative humidity $\left(20^{\circ} \mathrm{C}\right)$. shown in Fig. 3.

The collection efficiency of the impactor is determined by means of following two methods. In the first place, the air is drawn through two impactors of the same form by a rotary vacuum pump. The velocity of suction is so adjusted that it is approximately the same as that of hand-operated impactor. If it is assumed that the two impactors have the same collection efficiency $E$, the value of $E$ is determined by a formula $E=1-n_{2} / n_{1}$ where $n_{1}$ and $n_{2}$ are the number of the particles collected on the glass plates at the first and second stages of impactor respectively. Table 1

Table 1. Collection efficiency of impactor.

\begin{tabular}{c|c|c|c|c|c|c}
\hline \multirow{2}{*}{ Date } & Time & \multicolumn{3}{|c}{ Range of particle diameter $\mu^{*}$} \\
\cline { 3 - 7 } & JST & $2-3$ & $3-5$ & $5-10$ & $10-20$ & $20-30$ \\
\hline Oct. 29 & 1007 & 0.90 & 0.98 & 0.98 & 1.00 & - \\
1958 & 1032 & 0.91 & 0.93 & 0.95 & 1.00 & - \\
\hline Nov. 6 & 0502 & 0.99 & 0.99 & 1.00 & 1.00 & - \\
1958 & 0511 & 0.96 & 0.96 & 0.96 & 1.00 & - \\
& 0549 & 0.89 & 0.93 & 1.00 & 1.00 & - \\
& 0557 & 0.99 & 1.00 & 1.00 & 1.00 & - \\
& 0603 & 0.99 & 0.98 & 1.00 & 1.00 & - \\
& 0612 & 0.97 & 0.97 & 1.00 & 1.00 & 1.00 \\
\hline Nov. 14 & 0501 & 0.99 & 1.00 & 0.94 & 1.00 & 1.00 \\
1958 & 0509 & 1.00 & 1.00 & 1.00 & 1.00 & - \\
\hline \multicolumn{2}{c}{ Mean value } & 0.96 & 0.97 & 0.98 & 1.00 & 1.00 \\
\hline
\end{tabular}

* Diameter at relative humidity $95 \%$.

shows the results of the measurements, which indicate that most of the particles with radii above one micron are collected by the impactor.

The samplings of particles on glass slide exposed from aircraft have been universally employed in various places of the world. Then the comparison was made between the particle concentrations obtained by the slide technique with those by our impactor method during the flight on February 25, 1959. The flight measurements were made from 0830 to 0930 JST at several different heights over Sapporo with the velocity of the aircraft 125 knots. The glass slides with width about $3.5 \mathrm{~mm}$ were exposed to the air in 30 seconds. It was very fine at night preceding the flight 


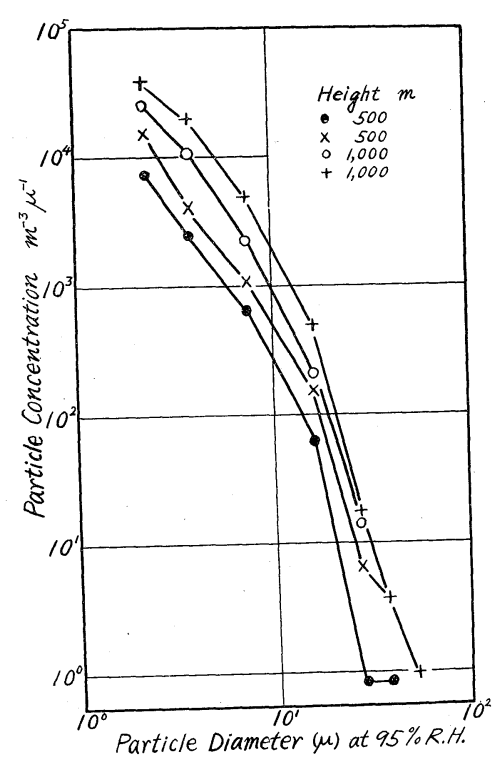

(a) Slide method

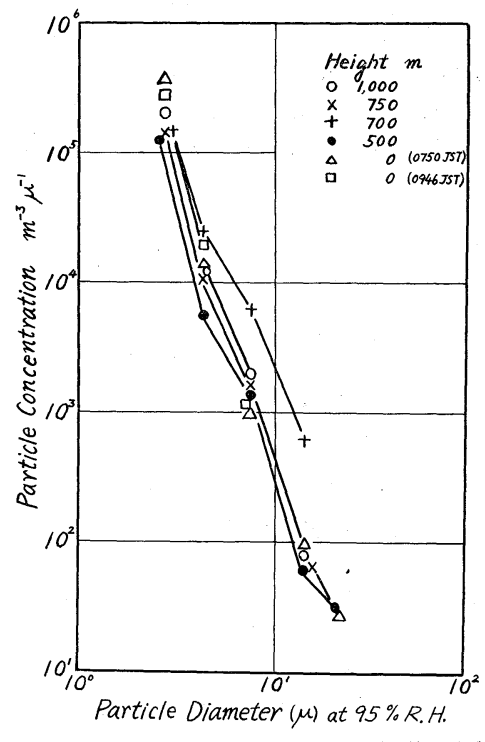

(b) Impactor method

Fig. 4. Size distributions of hygroscopic particles in the air over Sapporo on February 25, 1959.

so that the air was very stable and we saw a smoke belt formed over the Sapporo City flowing northwestwards at altitude 100 to $200 \mathrm{~m}$. The samplings by means of the impactor were also made on the ground before and after the flight.

Fig. 4 shows the results of the measurements. It is evident that the impactor method gives larger concentration of 2.5-micron particles than slide method. It is presumed that the collection efficiency calculated according to Langmuir's method gives too large values for the small particles. For the particles with size ranging from 3 to 15 microns both methods give approximately the same value, although the mean concentration by the slide method is somewhat larger than by impaction method. The concentrations of large particles with radii above 20 microns obtained by both methods are quite different, that is, slide method detects the particles of more than 30 microns in diameter, while the impactor method does not. Therefore the impactor is unfavorable for the measurements of these large particles.

Fig. 4 also shows that the particle concentration increases with height. Such phenomena are frequently found over the central U.S.A. by Byers and others (1957).

\section{Mass spectra of large and giant hygroscopic particles}

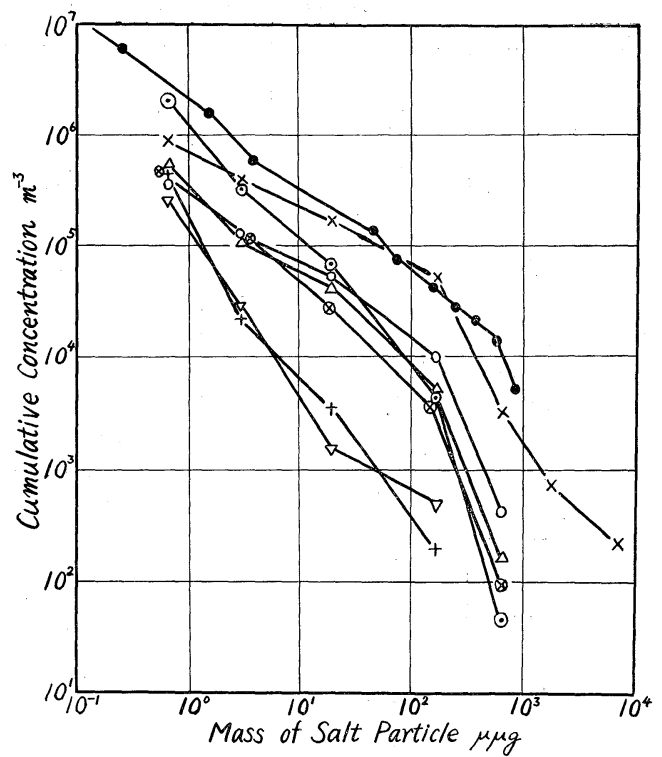

Fig. 5. Mass spectra of hygroscopic particles. $\times$ Tsugaru Strait, Yuriage, $\bigcirc$ Rumoi, + Mt. Taisetsu, $\triangle$ Shirogane, $\otimes$ Asahikawa, April, OAsahikawa, autumn, $\nabla$ Sapporo (impactor)'

Fig. 5 shows the mean mass spectra of hygroscopic particles. In Table 2 the maximum 


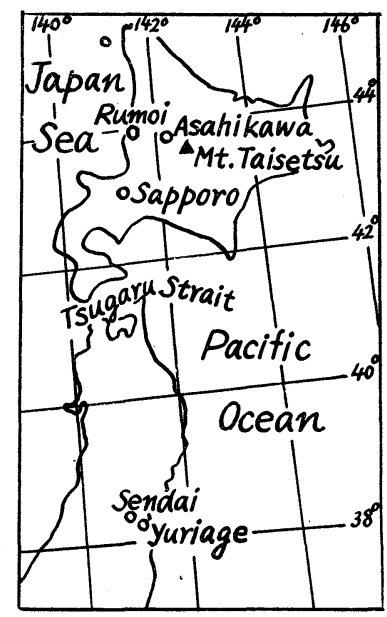

Fig. 6.

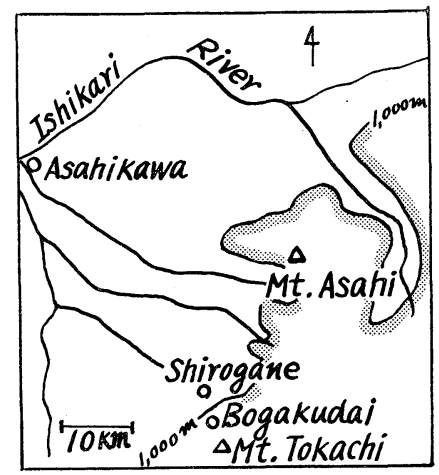

Fig. 7.

Table 2. Concentrations of hygroscopic particles.

\begin{tabular}{|c|c|c|c|c|c|c|}
\hline \multirow{4}{*}{$\begin{array}{l}\text { Sample } \\
\text { number }\end{array}$} & \multicolumn{5}{|c|}{ Particle diameter at $95 \%$ R.H. $(\mu)$} & \multirow{4}{*}{ Remarks } \\
\hline & \multicolumn{5}{|c|}{$2-3-5-30-30$} & \\
\hline & \multicolumn{5}{|c|}{ Mass of salt (g) } & \\
\hline & \multicolumn{5}{|c|}{$3.3 \times 10^{-13}-1.1 \times 10^{-12}-5.2 \times 10^{-12}-4.2 \times 10^{-11}-3.3 \times 10^{-10}-1.1 \times 10^{-9}$} & \\
\hline \multirow{3}{*}{$(1)$} & $5.7 \times 10^{5}$ & $2.6 \times 10^{5}$ & $1.4 \times 10^{5}$ & $5.4 \times 10^{4}$ & $6.0 \times 10^{3}$ & Max. \\
\hline & $4.8 \times 10^{5}$ & $2.2 \times 10^{5}$ & $1.2 \times 10^{5}$ & 4. $6 \times 10^{4}$ & $3.0 \times 10^{3}$ & Mean \\
\hline & $3.9 \times 10^{5}$ & $1.9 \times 10^{5}$ & $1.0 \times 10^{5}$ & $3.7 \times 10^{4}$ & $1.0 \times 10^{3}$ & Min. \\
\hline \multirow{3}{*}{$(2)$} & $2.4 \times 10^{6}$ & $3.8 \times 10^{5}$ & 1. $4 \times 10^{5}$ & $9.6 \times 10^{3}$ & 3. $0 \times 10^{2}$ & Max. \\
\hline & 1. $7 \times 10^{6}$ & $2.6 \times 10^{5}$ & $6.5 \times 10^{4}$ & $4.7 \times 10^{3}$ & 5. $0 \times 10$ & Mean \\
\hline & $4.8 \times 10^{5}$ & $5.4 \times 10^{4}$ & 1. $6 \times 10^{4}$ & 6. $7 \times 10^{2}$ & $\longrightarrow$ & Min. \\
\hline \multirow{3}{*}{ (3) } & 1. $1 \times 10^{6}$ & 4. $0 \times 10^{4}$ & 1. $2 \times 10^{4}$ & 7. $0 \times 10^{2}$ & $\longrightarrow$ & Max. \\
\hline & $4.4 \times 10^{5}$ & 1. $7 \times 10^{4}$ & $3.5 \times 10^{3}$ & $2.0 \times 10^{2}$ & - & Mean \\
\hline & $1.9 \times 10^{5}$ & $7.2 \times 10^{3}$ & $1.0 \times 10^{3}$ & - & 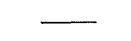 & Min. \\
\hline \multirow{3}{*}{$(4)-S$} & $5.2 \times 10^{5}$ & 1. $2 \times 10^{5}$ & 8. $3 \times 10^{4}$ & 1. $6 \times 10^{4}$ & $6.7 \times 10^{2}$ & Max. \\
\hline & $4.4 \times 10^{5}$ & $6.8 \times 10^{4}$ & $3.5 \times 10^{4}$ & $5.5 \times 10^{3}$ & 1. $7 \times 10^{2}$ & Mean \\
\hline & $3.4 \times 10^{5}$ & $2.7 \times 10^{4}$ & $9.7 \times 10^{3}$ & - & 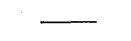 & Min. \\
\hline$(4)-B$ & 1. $0 \times 10^{5}$ & $2.8 \times 10^{3}$ & 2. $0 \times 10^{3}$ & $3.3 \times 10^{2}$ & - & \\
\hline \multirow{3}{*}{ ( 5 ) } & $9.0 \times 10^{5}$ & 1. $6 \times 10^{5}$ & $5.5 \times 10^{4}$ & 1. $2 \times 10^{4}$ & $6.6 \times 10^{2}$ & Max. \\
\hline & $3.3 \times 10^{5}$ & $8.6 \times 10^{4}$ & $2.3 \times 10^{4}$ & $4.1 \times 10^{3}$ & 1. $0 \times 10^{2}$ & Mean \\
\hline & 1. $2 \times 10^{4}$ & 4. $8 \times 10^{3}$ & $6.5 \times 10^{2}$ & $3.3 \times 10^{2}$ & - & Min. \\
\hline \multirow{3}{*}{ (6) } & 3. $6 \times 10^{5}$ & 1. $0 \times 10^{5}$ & $8.5 \times 10^{4}$ & $1.3 \times 10^{4}$ & $6.7 \times 10^{2}$ & Max. \\
\hline & $2.4 \times 10^{5}$ & 6. $0 \times 10^{4}$ & $4.2 \times 10^{4}$ & 1. $0 \times 10^{4}$ & 4. $6 \times 10^{2}$ & Mean \\
\hline & $3.5 \times 10^{4}$ & $1.9 \times 10^{4}$ & $5.3 \times 10^{3}$ & $3.3 \times 10^{2}$ & & Min. \\
\hline \multirow{3}{*}{ ( 7 ) } & $3.8 \times 10^{5}$ & $3.8 \times 10^{4}$ & $3.8 \times 10^{3}$ & $2.5 \times 10^{3}$ & - & Max. \\
\hline & $2.2 \times 10^{5}$ & $2.6 \times 10^{4}$ & 9. $0 \times 10^{2}$ & $5.7 \times 10^{2}$ & & Mean \\
\hline & $1.3 \times 10^{5}$ & $1.4 \times 10^{4}$ & - & - & & Min. \\
\hline
\end{tabular}

S: at Shirogane B: at Bogakudai 
and minimum concentrations are shown as well as the mean concentration. The time and places of the samplings are as follows (see Figs. 6 and 7).

(1) On May 12 and 24, 1958 two samplings were made in the center of the Tsugaru Strait on the deck of a ferry boat.

(2) On July 13, 1958 eight samplings were made at Rumoi, on the coast of Japan Sea.

(3) On August 11 and 12, 1957 seven samplings were made at $\mathrm{Mt}$. Taisetsu with elevation above $1,700 \mathrm{~m}$.

(4) On August 6, 1959 one sampling was made at Shirogane. At 0433, 0732 and 0845 JST of August 10, 1959 three samplings were made at Shirogane. At 0610 JST of August 10, 1959 one sampling was made at Bogakudai.

(5) In the period of April 1 to 23, 1958 seventeen samplings were made at Asahikawa usually once in a day.

(6) In the autumn (September 2 and 6, October 29, November 6 and 14 in 1958, and September 14, 17 and 23 in 1960) sixteen samplings were made in Asahikawa.

(7) In the flight measurements made over Sapporo on February 25, 1959 six samplings were made by means of impactor.

In Fig. 5 the mean spectrum obtained by Ogiwara and Okita (1951) at Yuriage, on the Pacific coast is also shown.

It is found that the concentration at the Tsugaru Strait is larger than those at other places and is comparable with that at Yuriage. It is marked that the concentrations of the particles of mass above $10 \mu \mu \mathrm{g}$ at Rumoi are considerably smaller than those at Yuriage, although both sampling sites are on the coast and there were sea breezes during the samplings. At Yuriage the wind velocites were about 2.5 and $7.0 \mathrm{~m} / \mathrm{sec}$ in the morning and afternoon respectively, while at Rumoi the velocity ranged from 1.1 to $2.8 \mathrm{~m} / \mathrm{sec}$. At Yuriage the particle concentration in the afternoon was about twice larger than that in the morning. Woodcock's measurements near cloud base over sea near the Hawaiian Island (Woodcock, 1953) reveal that the particle concentration increases with increasing wind force. Therefore the variation of the concentra- tion at Yuriage and the difference of the particle concentrations at Yuriage and Rumoi may be partly explained by the difference of the velocity of sea breeze. However, it is difficult to explain the very low concentration of the giant particles with masses above $100 \mu \mu \mathrm{g}$ at Rumoi and it is supposed that large scale circulation and other factors greatly influence the concentration.

The data obtained at inland area of Hokkaido (at Asahikawa and Shirogane) show nearly the same concentration irrespective of place and season, which are about one tenth of the concentration over the sea. Some samplings were made at around Mt. Asahi, which was only less than $300 \mathrm{~m}$ below the base of cumulus clouds. The concentration of $0.7 \mu \mu \mathrm{g}$ particles is independent of height, whereas the concentration of the particles with mass larger than $10 \mu \mu \mathrm{g}$ is about one tenth of that on the plain.

One sampling was made at Bogakudai (altitude 1,250 m) at 0610 JST on August 10, 1959 during the observations of large cloud droplets in the stratus clouds (Okita, 1962). At Bogakudai the air descended along the slope of Mt. Tokachi. The measured concentration shown in Table 2 is approximately the same as those obtained at Mt. Asahi. On the other hand, Shirogane (altitude $650 \mathrm{~m}$ ) was in the ascending air current. Therefore the distinct discontinuity of particle concentrations was observed between upper descending and lower ascending air.

It is marked that on February 25, 1959 at Sapporo very low concentrations were found throughout the layer from the ground up to the height of $1,000 \mathrm{~m}$. May be the air with low particle concentration subsided to the lower layer in the local anticyclone developed over Hokkaido.

Some of the mass spectra obtained by several investigators are shown in Fig. 8 (Fouriner d'Albe, 1957; Moore and Mason, 1954). Comparing the spectra in Fig. 8 with our results shown in Fig. 5 it is found that our values over the sea and on the coast are the same or somewhat higher than the oceanic and coastal values in Fig. 8. Our inland values obtained at about $100 \mathrm{~km}$ from the coast are approximately the same as those at Karachi and Hyderabad, which are situated on the coast and at $200 \mathrm{~km}$ from the coast 


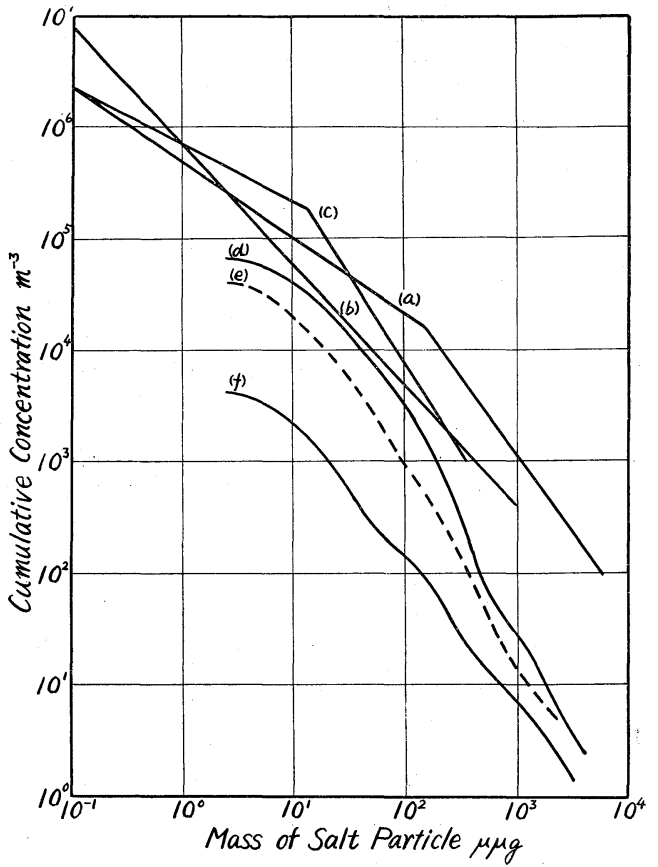

Fig. 8. Mass spectra of salt nuclei in air according to some investigators.

$\left.\begin{array}{r}\text { Moore \& Mason (a) I } \\ \text { (b) II }\end{array}\right\}$ Atlantic Ocean

Fournier d'Albe (c) Bay of Monaco

(d) Karachi

(e) Hyderabad

(f) Lahore

respectively. The value at Lahore indicates that the particle concentration is considerably reduced at a distance of about $1,000 \mathrm{~km}$ from the coast.

It is concluded from the above discussion that most of the giant hygroscopic particles are sea-salt particles and that the spectra obtained by the author can also be applied to other locations if they have the similar geographical conditions.

\section{Estimation of the possibility of giant hygroscopic particles as the nuclei of drizzle droplets}

In the early morning of August 10, 1959 we made the observations of the growth of large droplets in the stratus cloud. Their detailed analysis (Okita, 1962) indicates that 45-micron radius droplets formed near the top of the clouds grow to drizzle droplets by the accretion of cloud droplets in the ascending air current and that the concentration of large droplets of radii above 50 microns is between 100 and 5,800 per $\mathrm{m}^{3}$ of air. As the measurements of giant hygroscopic particles are also made at the cloud base we shall examine the possibility of these giant particles as the nuclei of large droplets.

The particle measurements on August 10 indicate that about 1,000 particles with masses above $400 \mu \mu \mathrm{g}$ are contained in one $\mathrm{m}^{3}$ of air at the base of the stratus cloud (Fig. 5 and Table 2). The $400 \mu \mu \mathrm{g}$ sodium chloride nuclei will grow by condensation and by coalescence with smaller cloud droplets while they are ascending through the cloud.

According to the theories of Ogiwara and Kobayashi and of Langmuir the growth of the droplets of aqueous solution of sodium chloride by condensation and by coalescence is expressed by the equation

$$
\frac{d R}{d z}=\frac{\frac{3 \alpha m D F \rho_{s}}{4 \pi R^{4}}+\frac{W}{4}\left(\frac{R+r}{R}\right)^{2}\left(v_{l}-v_{s}\right) E}{V-v_{l}}
$$

where $m$ is mass of sodium chloride in the droplet, $D$ diffusion coefficient of water vapor in air, $\rho_{s}$ saturated water vapor density in air, $F\left(T_{0}\right)=\left[1+(D L / K)\left(\partial \rho_{s} / \partial T\right)_{T_{0}}\right]^{-1}, T_{0}$ temperature of droplet, $K$ thermal conductivity of air, $L$ latent heat of evaporation of water vapor and $\alpha$ is a constant which is equal to 0.962 for sodium chloride solution. $R$ is the large droplet radius, $z$ height, $W$ liquid water content, $r$ cloud droplet radius, and $V$ is ascending air velocity. $v_{l}$ and $v_{s}$ are the terminal velocity of fall of large and cloud droplets respectively. $E$ is the collection efficiency between large and small droplets.

A cloud model, in which the up-current velocity is $24 \mathrm{~cm} / \mathrm{sec}$, mean volume radius of cloud droplets 11 microns and liquid water content is $0.2 \mathrm{~g} / \mathrm{m}^{3}$, is considered. The thickness of the cloud necessary for the droplets to grow to 45 microns in radius is calculated by the numerical integration of the equation (1). The calculated thickness is $144 \mathrm{~mm}$. The observed thickness is about $300 \mathrm{~m}$.

The discrepancy of the calculated and observed results can be explained as follows. When the radius of the large cloud droplets formed on $400 \mu \mu \mathrm{g}$ nuclei attains 45 microns or more their fall velocity exceeds $24 \mathrm{~cm} / \mathrm{sec}$, 
so that they begin to fall from the middle layer of the cloud. The droplets formed on the nuclei with mass below $400 \mu \mu \mathrm{g}$, on the other hand, continue to rise and some of them attain 45 microns in radii at the cloud top. As their fall path in the cloud is longest it is probable that the droplets which reach the cloud top become the largest drizzle droplets. In any event, the above discussion indicates that there are enough giant hygroscopic nuclei for the production of drizzle at the stratus cloud base.

\section{References}

Byers, H.R., J.R. Sievers and B.J. Tufts (1957): Distribution in the atmosphere of certatin particles capable of serving as condensation nuclei. Artificial Stimulation of Rain, Pergamon Press, 47.

Fournier d'Albe, E.M. (1957): Observations of the geographical distribution of giant hygroscopic nuclei, ibid., 135.

Isono, K., H. Fujita and M. Komabayashi (1956): Change in droplet spectrum and water content of a cloud induced by salt water seeding. Journ. Met. Soc. Japan, 34, 177-184.

Keith, C.H. and A.B. Arons (1954): The growth of sea-salt particles by condensation of atmos- pheric water vapor. Journ. Met., 11, 173-184.

Langmuir, I. (1948): The production of rain by a chain reaction in cumulus clouds of temperatures above freezing. Journ. Met., 5, 175-192.

Ludlam, F.H. (1951): The production of showers by the coalescence of cloud droplets. Quart. J. Roy. Met. Soc., 77, 402-417.

Moore, D.J. and B.J. Mason (1954): The concentration, size distribution and production rate of large salt nuclei over the oceans. ibid., 80, 583590.

Ogiwara, S. and T. Kobayashi (1954): On the growth of water droplets around hygroscopic particles in convective cloud and its application to the artificial precipitation. Report of Rainmaking in Japan, 1, 42-54.

Ogiwara, S. and T. Okita (1951): The size distribution of sea-salt nuclei and its contribution to visibility. Journ. Met. Soc. Japan, 29, 119-129 (in Japanese).

Okita, T. (1962): Observations of vertical structure of stratus cloud and radiation fogs in relation to mechanism of drizzle formation. (to be published in Tellus.)

Woodcock, A.H. (1952): Atmospheric salt particles and raindrops. Journ. Met., 9, 200-212.

Woodcock, A.H. (1953): Salt nuclei in marine air as a function of altitude and wind force. Journ. Met., 10, 362-371.

\section{大気中における巨大吸湿性粒子濃度}

$$
\text { 大 喜 多敏一 }
$$

(国立公衆衛生院労働衛生学部)

\footnotetext{
インパクターを用いて大気中の大きな吸湿性粒子を捕集し，その質量分布を求めた。測定結果は世界の他の地域で 求められた結果とよく一致し, 粒子濃度は海上または海岸で最大で海岸より約 $100 \mathrm{~km}$ の内陸では濃度が $1 / 10$ と減 少し, さら飞高度 $2,000 \mathrm{~m}$ 付近では平地飞怙ける值の $1 / 10$ 飞減少する。これらの観測結果より考えて, 巨大吸湿性 粒子の源は海洋であると考えられる。

さらと層雲の雲底と扔いて霧雨をもたらすと十分な個数の巨大吸湿性粒子を見いだした。
} 